\title{
Leiomyosarcoma and Endometrial Stromal Sarcoma Clinical Distant Metastasis TNM Finding v7
}

National Cancer Institute

\section{Source}

National Cancer Institute. Leiomyosarcoma and Endometrial Stromal Sarcoma Clinical

Distant Metastasis TNM Finding v7. NCI Thesaurus. Code C89603.

A clinical finding about one or more characteristics of leiomyosarcoma and endometrial stromal sarcoma, following the rules of the TNM AJCC V7 classification system as they pertain to distant metastases. (from AJCC 7th Ed.) 